\title{
Re-moralising or De-moralising?
}

\author{
The Coalition Government's approach to 'problematic' populations
}

\author{
Ruth Patrick and Kate Brown* \\ University of Leeds
}

\begin{abstract}
The relationship between 'morality' and social policy has been a preoccupation of the Coalition Government in the UK since it came to power in May 2010. Social unrest has intensified this interest as well as playing a role in reinvigorating longstanding public debates on the ethics of social welfare. Speaking in the aftermath of the riots and looting which took place in August 2011, the Prime Minister framed the problems in terms of a crisis of moral standards: 'some of the worst aspects of human nature tolerated, indulged - sometimes even incentivised - by a state and its agencies that in parts have become literally de-moralised' (Cameron, 2011). Having already embarked on substantial efforts to redraw the boundaries of the welfare state via initiatives such as 'free' schools, housing benefit and welfare reform and the introduction of student fees, the Government's response to such unrest seems to have been to step-up the 'remoralisation' agenda, enhancing welfare sanctions for 'misbehaviours' and further penalising failure to participate adequately in the labour market. We also seem to be witnessing something of a resurgence in ideas associated with theorists such as Larry Mead (1986) and Charles Murray (1984), with Ken Clarke asserting in his address to the 2011 Conservative Party Conference that a 'feral underclass' threatened to undermine the moral fabric of the rest of society (Clarke, 2011).
\end{abstract}

The social welfare system in the UK is now increasingly seen as an important means of maintaining particular moral standards and disciplining perceived transgression. Proposals to withdraw Housing Benefit from families involved in the riots, moves to increase fines for criminal offences perpetrated by welfare claimants and the 'cap' on Housing Benefit entitlement for families claiming amounts above the 'average' wage are all notable recent examples. Critics of such trends have argued that, too often, the focus on those at the 'bottom' of society is disproportionate to the lack of attention given to those nearer the 'top' in terms of how they benefit from or are governed by welfare arrangements (Sinfield, 1978). This may be changing, as there is some evidence of a growing perception that a 'moral deficit' also exists amongst wealthier sections of society. Undertakings such as stripping former Royal Bank of Scotland Chief Executive Fred Goodwin of his knighthood and the considerable political attention given to individual bonuses of other selected high-ranking bankers would indicate that this idea seems to now have been taken up across the political mainstream. Meanwhile, those whom Ed Miliband calls the 'squeezed middle' and whom George Osborne and Nick Clegg have referred to as 'alarm clock Britain' remain largely unimplicated in the debate on how best to 're-moralise' society. 
The morality of welfare is a long running and well-discussed issue in social policy (Clarke, 2005; Dwyer, 2004; Levitas, 1998; Marquand, 1996; Raco, 2009). To some extent, developments under the Coalition Government are largely a continuation of trends under New Labour. Post-1997, something of a moral consensus about the need for welfare 'conditionality' seems to have emerged across the political spectrum (Deacon and Patrick, 2011), and at the same time we have witnessed declining public enthusiasm for universal entitlements (British Attitude Survey, 2010). However, in the present context of economic austerity, rising unemployment and increasing benefits costs, important shifts are taking place in social and political attitudes to 'fairness'. New positions are emerging on enduring questions of how far 'luck', circumstance, and opportunity connect with personal agency and individual 'responsibility' and these seem to be legitimising an increasingly selective and discriminatory system of welfare. Changes in entitlement are perhaps most extreme in relation to those sections of the population who are configured in the public imagination as 'problem' groups. This special edition aims to explore such developments in social welfare under the Coalition Government through a focus on four selected policy domains: worklessness, drug use, lone parenting and welfare for 'the vulnerable'.

The idea for the collection emerged from a symposium on 'Behaviourism and Social Policy' which took place in June 2011 at the University of Leeds. Four 'early career' researchers presented to a panel of specially selected social policy experts, with the experts encouraging the development of ideas into a special edition for People, Place and Policy Online. Distinct themes emerged across the talks and discussion on the day, the most striking of which seemed to be a're-moralisation' of social policy from 1997 onwards. In their presentations, researchers had each noted that Coalition Government policy had thus far deployed moral discourses largely similar to New Labour in terms of 'rights' and 'responsibilities', but also that we have been seeing an acceleration in the process of narrowing entitlements. Working together, the researchers selected areas of common ground across their fields of research, and decided to explore them collectively. Thanks go to the organisers of the symposium, Malcolm Harrison and Teela Sanders, invited experts Peter Dwyer, John Flint, Judy Nixon, and Emma Wincup, and our collaborators on the special edition and editorial, Laura Davies and Mark Monaghan.

This special edition features papers on worklessness (Patrick), drug use (Monaghan), lone parenting (Davies) and welfare for 'the vulnerable' (Brown). The four papers share a central concern with examining how and in what ways social policy is being 're-moralised' under the Coalition Government. While accepting that a moralising sub-text to social policy agendas has a long history (Clarke, 2005; Raco, 2009), this collection highlights the novelties within the approach taken by the Coalition and offers tentative thoughts on how their moralising project is unfolding. One particularly notable theme relates to the emergent and resilient divisions between populations of deserving and undeserving, citizens and non-citizens, workers and non-workers, 'good' and 'bad' families and so on. While distinctions between the deserving and undeserving stretch back further than the history of the welfare state itself (Warren, 2005), this collection pays particular consideration to the ways in which these divisions are operating in the contemporary era. It explores how policymakers are reshaping boundaries so that an ever greater proportion of the poorest in society are subsumed within the 'undeserving' category. Brown's paper also considers how even the 'deserving' and 'vulnerable' can be affected by such divisions in ways that are not entirely benevolent.

Another central theme to emerge from the collection is a concern with the consequences of the continued creeping conditionality in welfare entitlement (Dwyer, 2004). As both Monaghan and Davies demonstrate in their respective papers, the tools of welfare conditionality are increasingly utilised in efforts to persuade and even 
compel 'problematic' populations to behave as the government would like. The continued expansion of welfare conditionality inevitably impacts on the social rights of citizenship (Dwyer, 2010), and the overarching implications for social citizenship of a moralising social policy agenda towards sub-sections of society is a theme that cuts across each of the papers in this collection. Authors explore which groups are included as citizens in the context of today's re-moralised social policy arena, considering how far and in what ways new groups are being included and excluded from citizenship. Here, the dominance of paid work in determining full citizenship status emerges as a key theme as does the on-going effort to re-integrate many of those not currently in work (including many disabled people, drug users and lone parents) into the labour market and thus into the citizenry. Possible impacts of a repeated emphasis on work as the passport to full citizenship are explored, most notably in the papers by Davies and Patrick, while Brown also gives close consideration to how 'vulnerable' populations fare in terms of their inclusion or exclusion as citizens in contemporary Britain.

This collection represents an early attempt to track and explore the reforms and 'moralising' of the Coalition in just four policy domains. It offers insights and reflections from works in progress by four 'early career' researchers and the papers arguably pose as many questions as they answer. Additional areas to explore might include how far the valorisation of work affects those who choose not to work due to independent financial resources and whether rich non-workers are also affected by the equation of work with responsible citizenship. How far the 're-moralising project' will extend beyond the poorest to affect government's treatment of 'irresponsible' citizens at the top of the income scale - or to include new discursive categories such as the 'squeezed middle' and 'alarm clock Britain'- also needs further investigation. At a time when policy landscapes are changing at such a rapid pace, it is critical that academics continue to monitor and critique both the explicit and more subtle shifting moral messages about supposedly 'problematic' groups which develop alongside these reforms. This edited collection aims to make some contribution to this broader body of work.

* Correspondence address: Ruth Patrick and Kate Brown, School of Sociology and Social Policy, University of Leeds, Leeds, LS2 9JT. Email: r.patrick@leeds.ac.uk / k.e.brown@leeds.ac.uk

\section{References}

Cameron, D. (2011) Fightback after the riots speech, 15th August 2011.

Clarke, J. (2005) New Labour's citizens: activated, empowered, responsibilized, abandoned? Critical Social Policy, 25, 4, 447-463.

Clarke, K. (2011) Prison with a purpose speech to the Conservative Party Conference, $4^{\text {th }}$ October 2011.

Deacon, A. and Patrick, R. (2011) A new welfare settlement? The Coalition government and welfare-to-work in: $\mathrm{H}$. Bochel (ed), The Conservative Party and Social Policy. Bristol: The Policy Press.

Dwyer, P. (2004) Creeping conditionality in the UK: From welfare rights to conditional entitlements? Canadian Journal of Sociology, 29, 2, 265-287.

Dwyer, P. (2010) Understanding Social Citizenship, themes and perspectives for policy and practice, Second Edition. Bristol: The Policy Press.

Levitas, R. (1998) The Inclusive Society? New Labour and Social Exclusion. Basingstoke: Palgrave Macmillan.

Marquand, D. (1996) Moralists and Hedonists, in: D. Marquand and A. Seldon (eds.) The Ideas that Shaped Post-War Britain. London: Harper Collins. 
Mead, L. (1986) Beyond Entitlement. New York: The Free Press.

Murray, C. 1984. Losing Ground. New York: Harper Collins.

Raco, M. (2009) From expectations to aspirations: State modernisation, urban policy, and the existential politics of welfare in the UK. Political Geography, 28, 7, 436444.

Sinfield, A. (1978) Analyses in the Social Division of Welfare. Journal of Social Policy, 7, $2,129-56$.

Warren, J. (2005) Disabled people, the state and employment: historical lessons and welfare policy, in: A. Roulstone and C. Barnes, (eds.) Working Futures? Disabled people, policy and social inclusion. Bristol: The Policy Press. 